\title{
Investing In Leadership, Governance And Management To Improve Quality Of Teaching And Learning: A Human Capital Perspective
}

Isaac M. Ntshoe, Central University of Technology, South Africa Jacob M. Selesho, Vaal University of Technology, South Africa

\begin{abstract}
While funding is undoubtedly necessary to promote the quality of the curriculum, teaching, and learning, funding in and by itself is not a guarantee to achieve equity and equality of outcomes. Accordingly, in some cases, such as the South African context, a sound funding regimen to address inequities and quality in education in the post-apartheid setting, the quality of leadership, governance and management are equally key and sometimes more critical to achieving sustainable quality and equity improvements in education, including the quality of matric learners.
\end{abstract}

Five quintile 1s (non-fee paying schools) in the Fezile Dabi district in the Free State Province of South Africa were sampled for this study. The schools were used as samples because they formed what is known as non-performing schools in terms of their matric results for the 2009 and 2010 academic years. We used purposive sampling comprising schools that did not perform satisfactorily in their matric results and adopted an utilisation-focused strategy that could assist the Free State Department of Education to improve quality. The data were collected from School Management Teams comprising the school principals of the five schools and Heads of Department.

Knowledge of how principals manage the curriculum in schools in South Africa is therefore limited. Although there are detailed normative frameworks (often from elsewhere) on what principals should do, there is little consideration of the reality of the work of principals, in particular contexts, and what they actually do. There was a concern about some HODs with regard to their content knowledge of the different subjects' streams. There was an outcry of $45 \%$ of HODs in highly cognitive subjects, such as Mathematics, Accounting, and Physical Science, who did not possess the content knowledge required in their respective subjects' streaming. Consequently, a statement was made concerning the level of leadership in high-focus subjects. Similarly, there is a perception that there should be a strong content knowledge from the HOD as an instruction leader as their subjects are regarded as highly skilled subjects.

Keywords: Leadership; Governance; Management; Quality; Human

\section{INTRODUCTION}

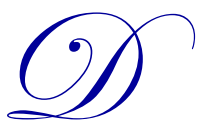

espite increased funding for school education since the new democratic elections of 1994, performance of South African students in mathematics and the sciences continues to rank lower than their counterparts in poor countries with meagre financial resources. Thus, the quality of matriculants who apply to tertiary education institutions remains a problem, generally, with learners ill-prepared to succeed in their studies. As a mechanism for redressing the historical inequitable distribution of education resources 
and improving the quality of education, the Department of Basic Education (DBE) in South Africa has introduced the quintile system in schools. This system categorises schools in terms of the ability or inability of parents to pay school fees and it analyses the poverty level of the community surrounding the school environment. As a strategy to redress past historical inequities, schools have been classified in terms of qualities 1 to 5 , with quintile 1 declared as no-fee schools. The funding of these different categories of schools is therefore influenced by quintiles in which schools are classified.

The purpose of this study is to examine the extent to which investing in leadership and management can impact positively on practice, in general, and the performance of matric students, in particular. The study premise is that categorising schools into quintile 1 (non-paying) cannot improve practice unless the leadership and management in a school are prioritised. This paper, therefore, examines the impact of leadership and management in school subjects in which students do not normally perform well, including English, Mathematics, Physical Science, and Accounting.

This study explores the role of leadership, governance, and management in creating sustainable quality and improved learning and teaching in quintiles 1 to 3 (no-fee paying schools) in the Fezile Dabi district in the Free State Province of South Africa. Quintiles in the South African schooling context refer to the classification of schools in terms of whether they charge school fees and how much they are expected to charge. Thus, schools in South Africa are categorised in terms of quintiles 1 to 5, with quintile 1 to 3 schools classified as non-fee paying schools.

The study takes the premise that the quality of the leadership, governance, and management in no-fee schools is critical to improving the quality of teaching and learning, in general, and the quality of matric students, in particular. The study takes the premise that the quality of the leadership, governance, and management in no-fees schools is critical to improving the quality of teaching and learning, in general, and the quality of matric students, in particular. The paper argues that for quality education to be delivered in these schools, leadership, governance, and management is fundamental. It further argues that the South African society, in general, measures the quality of education in terms of matric results, such that parents enrol their children in schools where minimal school fees are paid, rather than keeping them in no-fee schools of poor quality.

\section{Theoretical Framework}

Human capital and human resources development theories and a conceptual framework were used to foreground the study. Figure 1 provides a theoretical framework that guides this study and demonstrates the possible influence of Human Capital theory.

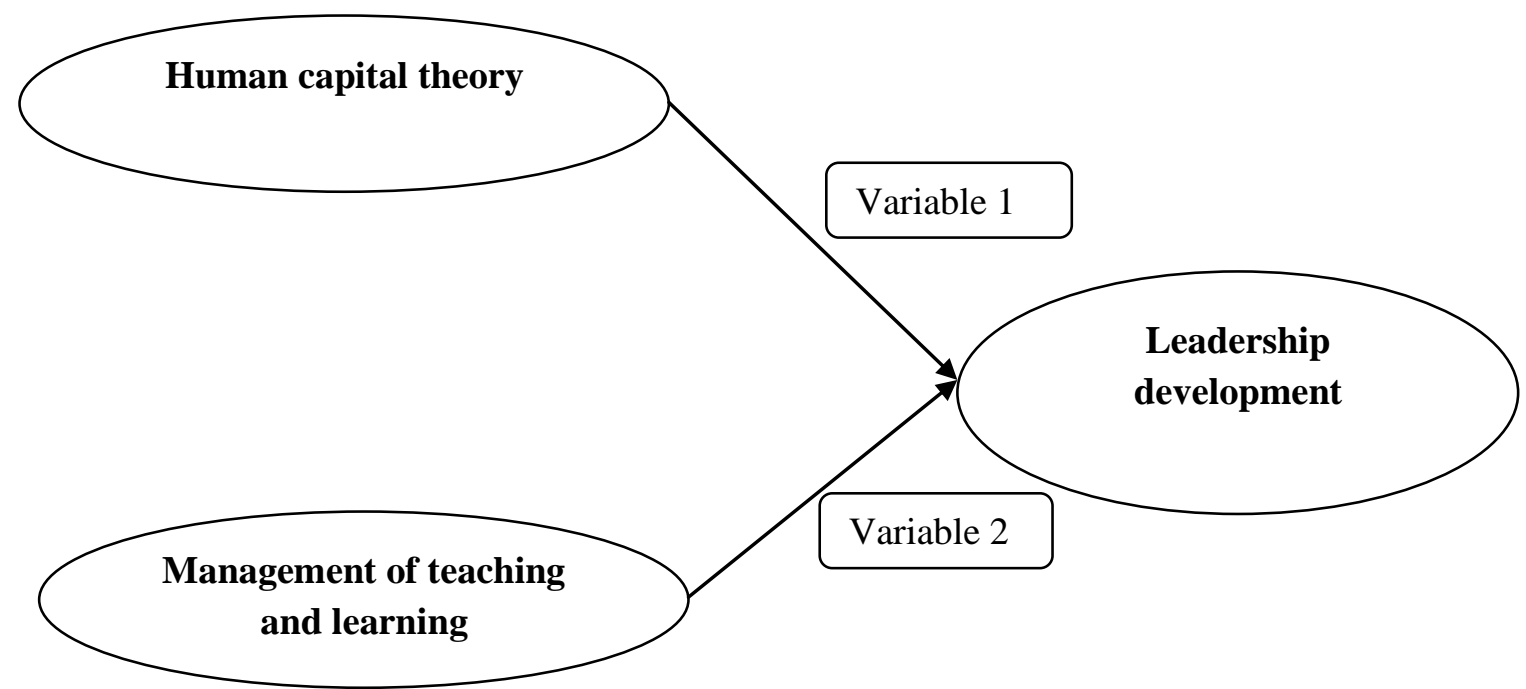

Figure 1: Framework on Leadership Development 


\section{Human Capital Theory}

Modern human capital theory traces its origins to the 1960s in the works of Becker (1975; Blaug, 1975; Denison, 1967; Smith, 1905; Schultz, 1961). Schultz (1961) and Becker (1975), in their theoretical and empirical work on the relationship between human capital investments, are the doyens in this field. Supporters of human capital theory assume that education and earnings are related. The set of skills which an employee acquires on the job, through training and experience, increases that employee's value in the marketplace. The underlying premise is that education as an investment, the externalities of education, and the social and individual rates of return are framed by human capital theory.

In one of his seminal works, Blaug analyses the notions of the 'public' and 'private' good of education and concludes that education represents what might be called a 'quasi-public good' because of the overlaps in terms of the economic benefits of, the investment in and consumption of education (1975, pp. 106-107). Thus, it is important to confront questions such as: 1) 'How important are 'externalities,' 'spill-over effects,' and 'neighbourhood effects' of education? and 2) "How large is the degree of 'publicness'?" (ibid.; Guido, 1999, p. 232).

Thus, lifelong learning, it is argued, originally emanated from the world of business and industry with the language of human capital theory and human resources investment (ibid., p. 48). This discourse "forcefully demanded the training and management of a new kind of worker/employee responding to the demands of postindustrial society, of post-Fordist enterprises of organisations" (Wain, 2000, p. 48).

There are three identifiable components of human capital: 1) early ability (whether acquired or innate), 2) qualifications and knowledge acquired through formal education, and 3) skills, competencies, and expertise acquired through training on the job.

- $\quad$ The concept of human capital arose from a recognition that an individual's or a firm's decision to invest in human capital (i.e., undertake or finance more education or training) is similar to a decision about other types of investments undertaken by individuals or firms.

- Human capital investments involve an initial cost (tuition and training course fees, forgone earnings while studying, and reduced wages and productivity during the training period) on which the individual or firm hopes to gain a return in the future (for example, through increased earnings or higher firm productivity).

- As with investments in physical capital, this human capital investment will only be undertaken by the wealth maximising individual or firm if the expected return from the investment (or 'net internal rate of return') is greater than the market rate of interest (Blundell, Dearden, Meghir, \& Sianesi, 1999, p. 6).

In most empirical studies, training is distinguished from formal school and post-school qualifications (which are viewed as education) and is generally defined in terms of courses designed to help individuals develop skills that might be of use in their job. What is clear from the studies when looking at the returns to training and participation in training is that of using highly-aggregated descriptions of 'training' (Blundell et al., 1999, p. 9).

A picture emerges of a strong complementarity between the three main components of human capital early ability, qualifications and knowledge acquired through formal education, and skills, competencies, and expertise acquired through training on the job. The current accumulated stock of human capital provides both strong incentives and more opportunities for further investments in human capital formation, thus highlighting the selfsustaining nature of individual human capital growth (Blundell et al., 1999, p. 9).

Investing in human capital vis-a-vis investing in the machine is that in the former, the focus is on the development of the competencies and skills of people and the assumption that the bearer of such competencies and skills will benefit an organisation in the long term. Accordingly, the focus is often on thinking ability or intelligence, leadership and management and interpersonal skills, including the ability to enhance the values of an organisation. 


\section{The Role of the School Management Team in Curriculum and Instruction}

Evidence suggests that of South Africa's over 12 million potential school children, more than $90 \%$ percent are in school - a far higher enrolment rate than in most other developing countries. Spending on education has increased exponentially in the post-apartheid era (South Africa Information, 2011). In 1994, the government spent R31, 8 billion on education. By 2006, this had risen to R92.1 billion, $17.8 \%$ of total government spending. At roughly $5 \%$ of the national Gross Domestic Product (GDP), South Africa's rate of investment in education is among the highest in the world. These figures tell an interesting a story that despite the unprecedented spending in education since the changes from the apartheid system to one of democracy, the quality of outcomes has not improved and, in some cases, quality has worsened when looking at student performance in matric and in the early years in higher education (South Africa Information, 2011).

In addition to increased spending in education, the qualifications of educators have also improved significantly in post-apartheid South Africa, with the percentage of under-qualified educators decreasing from 36 percent in 1994 to 26 percent in 1998. Various strategies, including the redeployment of educators, have been successfully employed to redistribute teachers to areas of greater need and establish more equitable learner/educator ratios. Whereas the average learner/educator ratio was 41:1 in 1994, by 2000, this average had changed to 35:1 (South Africa Information, 2011).

Thus, the triple spending in education and the fact that some of the non-performing schools have been categorised as non-fee paying suggest that funding is not the determining factor in improved curriculum, teaching, and learning. It might therefore be necessary to scrutinise the role of the School Management Team (SMT) in improving quality in curriculum and related pedagogies, including teaching and learning in under-performing schools.

For the purposes of this study, researchers assume that investing in the development of leadership and management competencies and skills of the School Management Team (SMT) will be cost-effective in improving practice in the chosen school subjects. The study therefore moves from the premise that despite the fact that the sample schools are categorised into quintiles 1,2, and 3, students' performance in the chosen subjects is unlikely to improve unless there is intervention in the leadership and management of curriculum learning instruction. The researchers further argue that the SMT, as an asset that the DBE has so far prioritised, needs to be developed, but also assessed, in order to judge its impact, especially in the subjects provided at a school.

It is argued that the SMT needs to undergo what is called continuous professional development to capacitate its members to face the challenges and changes brought about by advances in IT, advances in knowledge, changes in the curriculum, and to enable them to perform their role effectively and efficiently.

The urgent need to capacitate SMTs is even stronger, considering that the SMT in holding such a senior position may not have the necessary experience and subject expertise in the subject clusters they are leading and managing as Head of Departments (HoDs).

The SMT is also responsible for planning and managing the school's finances, which includes budgeting. The DoE (2000, p. 26) claims that "SMT members need to understand the financial position of the school and need to be able to participate in managing the school's finances, including helping with fundraising." This can be accomplished through ensuring that accurate financial records are being kept so as to enable SMT members to give an account of the use of funds (DoE, 2000, p. 26). The responsibility for managing teaching and learning is shared amongst the principal, the SMT, the heads of departments, and classroom educators. Educators manage curriculum implementation in their classrooms; HoDs have the responsibility of ensuring effective teaching and learning across their learning areas or phases, while principals and the school management team have a whole-school role (Bush, Joubert, Kigggundu, \& Van Rooyen, 2010, p. 164).

SMTs should share the overall responsibility with the principals. Where SMTs operate successfully, they have great potential to improve classroom practice through HoDs sharing their ideas, developing school-wide policies, and enacting consistent practice throughout the school (Bush \& Glover, 2009). 
When the empowering stage is reached, the SMT is making major decisions and feels capacitated to do so, with the principal in a supportive role - still accountable for decisions but having delegated the responsibility for action. To get to this stage, the principal has to lead his or her team through the other stages so that there is confidence that SMT members can do what is needed. Many principals get stuck at the participative stage and cannot make that ultimate move to hand over responsibility to others (DoE, 2008, p. 50).

The integrated quality management system (IQMS) Manual (DoE, 2005, p. 3) advises that the SMT and School Development Team (SDT) should work together and mutually support each another on matters relating to the IQMS. The Educators Manual (DoE, 2005, p. 3) states that SMTs contribute to the professional development of educators by liaising between schools and the Department of Education in respect of the in-service training (INSET) programme.

Chisholm argues that the IQMS is particularly notable for the linking of quality and accountability, and the management of teaching and learning in schools. She argues further that although the emerging accountability system is weak in terms of rewards and sanctions attached to adhering to requirements, it is onerous in terms of the demands placed on schools, especially in their administrative components (Chisholm, Hoadley, \& Kivilu, 2005, p. $4)$.

The DoE expects the SMT to implement its policies while, on the other hand, there is resistance on the part of educators who feel that sometimes SMT members oppress them. The allegation of being oppressors is targeted at SMT members more often than not, especially when they request educators to submit work for monitoring purposes (Sister, 2004, p. 21).

Research on the role of the principal in curriculum teaching and learning points to the following statements:

- $\quad$ Leadership that makes a difference is both position-based (principal) and distributive (administrative team and teachers), but both are only indirectly related to student outcomes.

- Organisational Learning (OL), or a collective teacher efficacy, is the important intervening variable between leadership and teacher work and then student outcomes.

- $\quad$ Leadership contributes to OL which, in turn, influences what happens in the core business of the school teaching and learning. It influences the way students perceive how teachers organise and conduct their instruction and their educational interactions with, and expectations of, their students.

The above statements also outline the objectives and roles of the HoDs in secondary schools. One of the primary roles of HoDs is to identify the best and most innovative teaching strategies to enhance learning. They are to lead teams of teachers to ensure that the curricula are developed, delivered, and assessed, that programmes are evaluated, and teachers appraised. They are also to select, prepare, and organise teaching-learning materials and encourage their effective use in the classrooms. Furthermore, HoDs are also required to plan and organise schoolbased workshops or short courses on specific topics and serve as advisors to the principal/senior assistant and their respective section heads (for schools with section heads). In short, they are responsible for the instructional programmes in their subject areas. Overall, HoDs play a pivotal role in the school and are recognised for their expertise in the respective subjects and teaching methodology. They are even recognised as "the engine room of change and a repository of expertise with up-to-date knowledge capable of transforming and energising teaching and learning" and the key to developing successful schools (Brown \& Rutherford, 1999).

HoDs, therefore, play a crucial role in managing the teaching-learning process and in ensuring the quality of teaching in schools. However, not much is known about the level of competencies of HoDs. Such a study would be useful to stakeholders, such as the Ministry of Education, in identifying the training needs of HoDs and in designing a training programme for them.

The Malaysian government has spent billions of ringgit in providing educational facilities and services toward realising this goal. It has invested heavily in providing various types of training and development programmes for public sector employees. Providing quality education and opportunities for professional development is important to ensure that people are open to new ideas, is ongoing and enables employees to deal with the rapid changes in this technologically challenging millennium (Onn \& Bak, 2010). 
Administration of the subject department refers to the ability to conduct departmental meetings, prepare, and allocate the annual budget for the department, purchase and store teaching-learning resources, plan the department's educational programme, and mobilise teachers in the department to ensure the successful implementation of departmental activities.

Curriculum development refers to competencies related to implementing the curriculum, to quality teaching and student learning and performance. This includes the tasks of obtaining the most up-to-date subject syllabus, ensuring that subject teachers adhere to the syllabus and schemes of work, that subject teachers have a good understanding of their subject matter to take the necessary steps to ensure student learning and to improve students' academic achievement.

Supervision and mentoring of teachers refers to the task of guiding, monitoring, and evaluating their subject teachers. This includes setting goals for their subject teachers, conducting reviews, and taking action within their departments, especially when students' academic performance has declined, and preparing the appraisal reports on their subject teachers.

Professional development of teachers includes identifying the development needs of teachers, providing guidance to teachers in improving themselves professionally, organising courses for teachers, and carrying out inhouse training for subject teachers. Interpersonal relations refers to the ability to maintain a healthy relationship with subject teachers, students, parents, and other school staff, and to consciously plan and encourage teachers to work as a team (Onn \& Bak, 2010, p. 466).

Harris and Muijs (2002, pp. 3-4) state that "one of the main barriers to teacher leadership concerns the 'topdown' leadership model that still dominates in many schools. The possibility of teacher leadership in any school will be dependent upon whether the head and the senior management team within the school relinquishes power to teachers and the extent to which they accept the influence of colleagues ... heads will therefore need to become 'leaders of leaders' striving to develop a relationship of trust with staff and encouraging leadership and autonomy throughout the school." To generate and sustain teacher leadership is seen as requiring not only empowerment but also time and opportunities for continuous professional development.

Effective teacher leadership also requires structural change. As Barth (2001, p. 115) points out, "To capture the potential of teacher leaders, the profession needs to invent, expand, and honour a variety of opportunities for teacher leadership so that there will be more choices than being "either' a principal or a teacher." The career progression for teachers has the most precious steps to get to the top. If more widespread teacher leadership is to be attained in our schools, educators will also have to explore multiple conceptions of the teacher's role - team leader, lead teacher, teacher researcher, or master teacher.

There is no more important form of 'school restructuring' than curriculum reform. Only when many such roles exist within the teaching profession will the potential benefit to schools be realised through teacher leadership and through teachers themselves. "In the next decade, 2.2 million new teachers will be needed to staff America's schools. Approximately two-thirds of the entire teaching profession will be replaced. Thus, the coming decade brings with it a profound opportunity to re-create the teaching profession" (Harris \& Muijs, 2002, p. 19).

The first aspect is the extent to which the curriculum is actually managed or whether it 'just happens' through teachers working interdependently. The second is the degree to which principals are involved in the management of the curriculum or whether it is left to the HoDs and teachers (Hoadley, Christie, \& Ward, 2009, p. 378). Thus, in the three key areas of principalship - financial management, instructional leadership, and human resource management - principals in South African schools have little experience and there is bound to be substantial confusion around who is responsible for what.

\section{METHODOLOGICAL PROCEDURES}

Five quintile 1 (no-fee paying schools) in the Fezile Dabi district in the Free State Province of South Africa were sampled for this study. The schools were used because they formed what is known as non-performing schools 
in terms of their matric results for the 2009 and 2010 academic years. The study made use of purposive sampling comprising schools that did not perform satisfactorily in their matric results and adopted an utilisation-focused strategy that could assist the Free State Department of Education to improve quality.

The data were collected from SMTs comprising the school principals of the five schools and HoDs. Policy and legislation on SMTs, as well as the schools' policy, provided the required data. Semi-structured focused interviews were conducted with HoDs and interviews with individual principals were done to collect data. We therefore analysed five schools' performance in subjects in which students often have problems, including Mathematics, English, Accounting, Physics, and Chemistry. It was at this stage that interviews were conducted with individual principals of each school and focus interviews with the HoDs in charge of the subject clusters with the purpose of eliciting information on leadership and the management of curriculum teaching and learning. While the intention was to ascertain the extent to which HoDs understand their roles, structures may differ in each subject cluster and we had to establish how effective they are in their own clusters. The study also used an observation schedule containing what could be considered as functioning schools to record the profile of each school.

The data were analysed by identifying emerging themes, patterns, and issues on the role of the SMT in providing leadership and the management of the curriculum and instruction in order to promote effective learning for the whole school and an improvement of the matric results.

\section{RESULTS AND FINDINGS}

Emerging themes, patterns, and issues drawn from empirical data and from the literature are as follows: leadership and management of curriculum, teaching, and instruction in a particular cluster; management of the curriculum, teaching, and instructions in a particular subject; influence among colleagues in the cluster; and the type of leadership and management provided by the principals and the role of the SMT in the curriculum and in instruction in a school.

Table 1: School Management Teams Population of Gender Chi Square (X)

\begin{tabular}{|l|c|c|c|}
\hline \multirow{2}{*}{ Gender } & \multicolumn{3}{|c|}{ School Management Team } \\
\cline { 2 - 4 } & $\boldsymbol{f}_{\boldsymbol{0}}$ & $\boldsymbol{f}_{\boldsymbol{e}}$ & $\boldsymbol{X}^{2}$ \\
\hline Female & 12 & 12.2 & 0.003 \\
\hline Male & 24 & 23.9 & 0.0004 \\
\hline Total & 36 & & \\
\hline
\end{tabular}

$\mathrm{X}^{2}=1.407, \mathrm{p}=0.5 \mathrm{df}=2$

From Table 1, results indicated that there was no significant relationship between SMT members' population and the gender representation. As indicated in the equity indices, the table proves gender lack of representation by females in leadership positions. This study proves that male teachers still - and continue to dominate the leadership profiles of the different schools in the province.

Table 2: School Management Teams Deliverable

\begin{tabular}{|l|c|c|c|c|}
\hline \multicolumn{2}{|c|}{ Items Or Activity } & \multicolumn{2}{c|}{ Yes } & \multicolumn{2}{c|}{ Nount } & \% \\
\cline { 2 - 5 } & Count & \% & 6 & $17 \%$ \\
\hline Effective Leadership & 30 & $83 \%$ & 6 & $17 \%$ \\
\hline Ability management of teaching and learning & 30 & $83 \%$ & 17 & $47 \%$ \\
\hline Sufficient content knowledge & 19 & $53 \%$ & 21 & $58 \%$ \\
\hline Job satisfaction & 15 & $42 \%$ & 4 & $12 \%$ \\
\hline Ability to motivate and influence others & 32 & $88 \%$ & 7 & $20 \%$ \\
\hline Ability to mentoring & 29 & $80 \%$ & 7 \\
\hline
\end{tabular}

Overall, it was noted that there was a high level of satisfaction with the way in which principals were managing the curriculum and doing their job. As reflected in Table 2, almost $83 \%$ of the SMT's component was satisfied with their performance, while $17 \%$ was not impressed by the performance of their managers with regard to curriculum management and coverage. When comparing the current core of leadership style with other professions, it is clear that principals generally are capable in their roles as stated by their colleagues. In addition, teachers were 
asked about the leadership style of their SMT's and whether it yields a positive influence with regard to the matric results; the majority (90\%) agreed that SMT leadership style influences their school's performance.

There was concern about some HODs with regard to their content knowledge of the different subjects' streams. It was expressed that $47 \%$ of HODs in highly cognitive subjects, such as Mathematics, Accounting, and Physical Science, did not possess sufficient content knowledge in their respective subjects. In this regard, a statement was made concerning the level of leadership in highly focused subjects. Similarly, there is a perception that there should be a sound knowledge of content from the HOD as an instruction leader, as their subjects are regarded as highly skilled subjects (see Table 2).

In some underperforming schools, it is obvious that $58 \%$ of the SMTs are more discouraged than in performing schools. For example, they were significantly less likely than SMTs in any other schools to believe that all learners in their school have access to expert teachers and high-quality teaching - a likely response to the much higher levels of underprepared teachers. It is also important to report that SMTs were also much less likely than their peers in other well-performing schools to report that their school had experienced an increase in staff confidence in the value of their work. They were also noticeably less likely than other SMT's to report increases over the last year in attention to the needs of low-performing students, the sharing of good practices among teachers, or the use of performance data on a quarterly basis to track learners' academic achievement and progress. While the majority (88\%) of these SMTs feel positive about their ability to influence school change and to make a difference in the lives of learners, they are significantly more likely than others in well performing schools to say that SMTs have too many responsibilities and that they are more likely to leave the job should they get the opportunity.

While the majority (70\%) of the SMTs intended to stay in their job - only if their schools registered a pass above the provincial benchmark - 75\% indicated that they would stay in their job until they reached retirement age. These differences were particularly pronounced for secondary schools SMTs, of whom only $30 \%$ plan to remain in their position until they retire. These concerns, no doubt, reflect some of the difficulties of being a SMT in an underperforming school where staffing and other resources have lagged far behind those of performing schools, but are very significant when seen against accountability pressures which have grown.

\section{Instruction Leadership Roles and Management Responsibilities}

In schools where instructional best practices exist and teachers are encouraged to teach to each learner's learning needs, almost all teachers (90\%) showed strong support for standards-based assessment. As we examined the data, we determined that the seven instructional best practices were significantly correlated and, thus too, interrelated to consider as separate factors. Instead, we regarded them as one variable. Furthermore, if teachers use one or more of these practices, they tend to use many of them.

\section{Management of Teaching, Learning, and Professional Growth}

Instructional leaders, who consistently emphasise, articulate, and boost teaching practices, which research identifies as instructional best practices, can increase their teacher's command of their subject specialisation and content-related matters. The majority of respondents (83\%) did agree that SMTs who, on a regular basis, deliberate with teachers about their instructional practices and student learning, are encouraging teachers. This gesture will ultimately enhance student learning. In doing so, instructional leadership can be examined and performance improved among learners. In the same vein, $80 \%$ of the respondents agree that their SMTs provide ongoing professional development in diverse formats to assist inexperienced teachers.

Teachers with more years of experience and with higher credentials believed that focus subjects are carrying quintiles 1 to 3 schools in an inaccurate direction. Vocational behavior theory may explain part of these teachers' responses. As a result, for teachers whose self-concept is moulded throughout their careers, if forced to alter his/her beliefs, it may be difficult and will ultimately challenge the teacher self-concepts. Therefore, it can be more difficult for individuals who have established behaviour patterns to change their beliefs and behaviours than it is for teachers who have not yet established a routine or built a strong professional identity. 
While $83 \%$ of effective SMT's understand their teachers' needs, the rest were not sure. Sensitive administrators recognise that some mature teachers need a fuller understanding of the new realities in order to reduce anxiety over unclear expectations. It is the role of the SMTs to provide a professional development programme for teachers; however, in the case of more experienced teachers who have been in the profession for a longer period of time, a targeted programme must be developed. The majority (90\%) of the SMT members were in favour of designing a continuous professional development programme geared toward more experienced teachers. This may help mature teachers to better understand the benefits of the new standards that accrue to the formally 'overlooked' students who slip through school with low expectations and poor achievement, which is masked by enrolment in the general curriculum and by the aggregated scores from higher achievers.

Experienced teachers believe that the curriculum's real-life relevance to learners is an important factor in successful learning. When learners understand and use information and skills in meaningful ways to better understand and solve problems in their own lives, learning is increased and skills are strengthened. When this does not happen in schools, teachers believe that learning suffers. Principals can help teachers enhance curricular relevance by frequently stressing that covering the content is not the same as learning the content. SMT's should continue to reassure teachers that effective instruction always has relevance to students' lives. It is understandable that pressured teachers want students to have the opportunity of learning the content and skills that will be assessed. Learning activities that involve meaningful applications to students, however, are more likely to be recalled and applied in a test than content rapidly covered without sufficient learning engagement.

\section{CONCLUSION}

Essentially, it is the responsibility of the SMT's to ensure that each learner succeeds in her academic endeavour. It is for this reason that the Education Amendments Act places the principal as the leader of the SMTs and the central figure in the learner's performance and accountability regarding academic achievement. The current research intends to establish the SMT and principal role with regard to leadership displayed in curriculum matters. Although most teachers value assessment and accountability as part of curriculum coverage, they feel hesitant about the implications of the assessment in Mathematics, Physics, Chemistry, Accounting, and English. It is imperative that when teachers lack confidence in a subject's content delivery, it is the responsibility of the principal, together with his SMT, to take charge of professional development and act as instructional leaders. Teachers indicated that when instructional best practices exist in their schools, when assessment is ongoing, and when weaker students have extra opportunities to learn, high-stakes testing takes public schools in the right direction.

Knowledge of how principals manage the curriculum in schools in South Africa is therefore limited. Although there are detailed normative frameworks (often from elsewhere) on what principals should do, there is little consideration of the reality of the work of principals, in particular contexts and what they actually do. Some clues are offered in relation to school management by early school effectiveness studies in South Africa; however, these studies show empirically, a number of school-level management practices that are associated with better than expected student performance in the country Africa (Hoadley et al., 2009). In particular, a recent study by Chisholm et al. (2005) shows how principals' time is largely consumed by administrative activities. The second factor is curriculum leadership and management, where management oversight of teachers constructing their plans, the monitoring of curriculum coverage, and the management of textbooks and stationery are associated with positive effects on student performance (Hoadley et al., 2009, p. 5).

\section{AUTHOR INFORMATION}

Isaac Ntshoe is a professor and occupies the post of Research Professor: Centre for Research in Academic, Vocational \& Professional Pedagogy (CRiAVPP), Faculty of Humanities at Central University of Technology, Free State. He has published widely in peer-reviewed journals in the field of policy in higher education, curriculum, and leadership. Professor Ntshoe has presented numerous papers at national and international conferences. E-mail: intshoe@cut.ac.za

Jacob Selesho is a professor and occupies the post of Research Professor: Faculty of Management Sciences at Vaal University of Technology. He has published widely in peer-reviewed journals in the field of higher education, 
schooling and leadership. Professor Selesho has presented numerous papers at national and international conferences. E-mail: jacobs@vut.ac.za (Corresponding author)

\section{REFERENCES}

1. $\quad$ Barth, R. S. (2001). Teacher leader Phi Delta Kappan, 82(6), 443-449.

2. Becker, G. S. (1975). Human capital: A theoretical and empirical analysis with special reference to education ( $2^{\text {nd }}$ Ed.). Massachusetts: National Bureau of Economic Research.

3. Bush, T., \& Glover, D. (2009). Managing teaching and learning: A concept paper. MGSLG, Johannesburg.

4. $\quad$ Bush, T., Joubert, R., Kiggundu, E., \& Van Rooyen, J. (2010). International Journal of Educational Development, 30(2010), 162-168.

5. Blaug, M. (1975). Introduction to economics of education. London: Penguin.

6. Blundell T., Dearden L., Meghir C., \& Sianesi B. (1999). Human capital investment: The returns from education and training to the individual, the firm and the economy. Fiscal Studies, 20(1), 1-23.

7. Brown, M., \& Rutherford, D. (1999). A re-appraisal of the role of the heads of department in UK secondary schools. Journal of Educational Administration, 37(3), 229-242.

8. Chisholm, L., Hoadley, U. K., \& Kivilu, M. (2005). Educator workload in South Africa. Report prepared for the education labour relations council. Pretoria: Human Sciences Research Council.

9. Denison, E. F. (1967) Measuring the contribution of education to economic growth. The residual factor and economic growth. Paris: OECD.

10. Department of Education. (2000). Education human resource management and development. Guides for School Management Teams. Pretoria: CTP Book Printers.

11. Department of Education (DoE). (2005). Training manual. Integrated quality management systems. Pretoria: Government printers.

12. Department of Education. (2008). Advanced certificate: Education (School management and leadership). Pretoria: Department of Education.

13. Guido, M. D. (1999). Commercialisation trends in higher education: The Costa Rican case. International Journal of Educational Development, 8(3), 228-243.

14. Fleish, B., \& Christie, P. (2004). Structural change, leadership and school effectiveness/improvement: Perspectives from South Africa. Discourse, 25(1), 95-111.

15. Harris, A., \& Muijs, D. (2002). Teacher leadership: Principles and practices. A paper for The National College for School Leadership, Nottingham, England.

16. Hoadley, U., Christie, P., \& Ward, C. L. (2009). Managing to learn: Instructional leadership in South African secondary schools. Retrieved 10 March 2011 from http://www.tandfonline.com/doi/pdf/ $10.1080 / 13632430903152054$

17. Mulford, B. (2003). School leaders: Changing roles and impact on teacher and school effectiveness. Leadership for Learning Research Group Faculty of Education University of Tasmania A paper commissioned by the Education and Training Policy Division, OECD, for the Activity Attracting, Developing and Retaining Effective Teachers. Retrieved 15 January 2011 from http://www.oecd.org/dataoecd/61/61/2635399.pdf

18. Onn, S., \& Bak, S. (2010). Competencies of secondary school heads of departments: Implications on continuous professional development. European Journal of Social Sciences, 14(3), 464.

19. Schulz, T. W. (1961). Education and economic growth. Social forces influencing American Education. Chicago: National Society for the Study of Education.

20. Sister, L. F. (2004). The role of school management teams in school improvement. Submitted in partial fulfilment of the requirements for the degree of Magister Educationist in the Faculty of Education at the Nelson Mandela Metropolitan University. Retrieved 15 March 2011 from http://www.nmmu.ac.za/documents/theses/lfsister.pdf

21. Smith, A. (1905). The wealth of nations. New York: P.F. Collier \& Son.

22. South Africa Information (2011). A huge investment in education. Retrieved 5 December 2011 from http://www.southafrica.info/about/social/govteducation.htm

23. Wain, K. (2000). A "learning society": post-modern politics. International Journal of Lifelong Education, 19(1), 40-52. 